СУХАНОВ М. О., асистент кафедри інтелектуальної власності, інформаційного та корпоративного права (Львівський наиіональний університет імені Івана Франка)

УДК 346.2

DOI https://doi.org/10.32842/2078-3736-2019-6-1-19

\title{
РОЛЬ СТАТУТУ В МЕХАНІЗМІ ПРАВОВОГО РЕГУЛЮВАННЯ КОРПОРАТИВНИХ ПРАВ ТА ОБОВ'ЯЗКІВ УЧАСНИКА ТОВАРИСТВА $З$ ОБМЕЖЕНОЮ ВІДПОВІДАЛЬНІСТЮ
}

У статті проаналізовано роль статуту в механізмі правового регулювання корпоративних прав та обов'язків учасника товариства 3 обмеженою відповідальністю. Досліджено поняття статуту у вітчизняній науці, законодавстві та в судовій практиці. Підтримано думку науковців, що статут є локальним правовим актом, обов'язковим для дотримання та виконання всіма учасниками товариства. Розглянуто загальні вимоги до змісту статуту товариств і визначено особливості змісту статуту товариства з обмеженою відповідальністю. У статті також звернуто увагу на те, що в законодавстві України закріплене право учасників товариства 3 обмеженою відповідальністю врегульовувати у статуті ті питання, які не врегульовані в законодавстві і можуть виникнути на практиці.

Окремо проаналізовані права й обов'язки учасників товариства 3 обмеженою відповідальністю, які закріплені в Законі України «Про товариства 3 обмеженою та додатковою відповідальністю» (статті 5-6). Наголошено, шо передбачення цих прав і обов'язків у статуті товариства $€$ зайвим та зроблено висновок, що в цьому локальному акті варто передбачати лише те, що вимагається законом, а також ті положення, щодо яких закон припускає специфіку локального, автономного, своєрідного регулювання. Визначено найпоширеніші права й обов'язки учасників товариства з обмеженою відповідальністю, які здебільшого передбачаються у статутах.

У статті також зазначається, що у статуті товариства з обмеженою відповідальністю неприпустимо вказувати мінімальну або максимальну кількість учасників. Визначено положення, які не можуть входити до змісту статуту.

Досліджено сутність, ознаки та завдання модельного статуту товариства 3 обмеженою відповідальністю. Розкрито особливості змісту модельного статуту товариства. Наголошується, що модельний статут товариства з обмеженою відповідальністю містить альтернативні норми з урегулювання питань щодо прав і обов'язків учасника товариства.

Ключові слова: корпоративні локальні акти, статут, модельний статут, зміст статуту, права учасників товариства з обмеженою відповідальністю, обов 'язки учасників товариства з обмеженою відповідальністю.

The article analyzes the role of the statute in the mechanism of legal regulation of corporate rights and obligations of a member of a limited liability company. The concept of statute in national science, legislation and jurisprudence is investigated. The position of scholars as to what the statute is a local legal act required for compliance and implementation by all participants is supported. The general requirements for

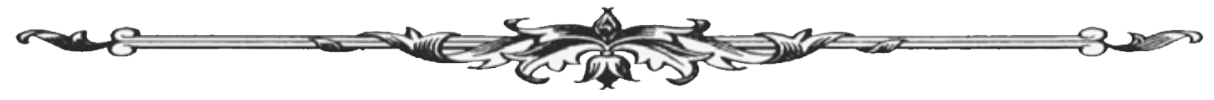


the content of the statute of the companies are considered and the features of the content of the statute of the limited liability company are determined. The article also draws attention to the fact that the legislation of Ukraine enshrines the right of members of a limited liability company to regulate in the statute those issues that are not regulated in the legislation and may arise in practice.

The rights and obligations of the members of the limited liability company, which are enshrined in the Law of Ukraine "On Limited and Additional Liability Companies" (Articles 5-6) are analyzed separately. The prediction of these rights and obligations in the statute of the company is superfluous and it is concluded that this local act should stipulate only what is required by law, as well as those provisions for which the law presupposes the specifics of local, autonomous, peculiar regulation is emphasized. The most common rights of members of a limited liability company, which are mostly provided for in the statutes, are identified

The article also states that the statute of a limited liability company does not allow specifying the minimum or maximum number of participants. The provisions, which cannot be included in the content of the statute, are identified. The article also states that the charter of a limited liability company does not allow specifying the minimum or maximum number of participants. The provisions, which cannot be included in the content of the statute, are identified.

The essence, features and tasks of the model statute of a limited liability company are investigated. The peculiarities of the content of the model statute of the company are revealed. It is emphasized that the model statute of a limited liability company contains alternative rules to regulate issues regarding the rights and obligations of a company member.

Key words: corporate local acts, statute, model statute, content of statute, rights of members of limited liability company, obligations of members of limited liability company.

Вступ. Сьогодні локальні корпоративні акти посідають вагоме місце в регулюванні корпоративних відносин, адже законодавець закріпив численні диспозитивні норми, що надають можливість учасникам товариств урегулювати у своїх внутрішніх документах прийнятну модель поведінки учасників товариства. Це переконливо свідчить про перевагу приватного характеру корпоративного права над публічним, яке покликано виконувати обслуговуючу роль для розвитку приватних відносин і для належного здійснення прав їх суб'єктів у своїх інтересах і без перешкод для всіх інших осіб. Найважливішим локальними актом товариства з обмеженою відповідальністю (далі - ТзОВ) $є$ статут, який є установчим документом і врегульовує питання щодо правового статусу учасників товариства.

Статуту як установчому документу ТзОВ приділялося чимало уваги в науково-правовій літературі. Ця проблематика була порушена у працях Т. Бровченко, О. Коротюка, В. Кочергіної, В. Кравчука, В. Петренка, О. Тичковою, М. Токар, О. Яворської, А. Яновицької й ін. Водночас слід зауважити, що майже всі дослідження статуту ТзОВ були проведені ще до ухвалення нового Закону України «Про товариства з обмеженою та додатковою відповідальністю». Отже, у наш час дослідження ролі статуту в механізмі правового регулювання корпоративних прав і обов'язків учасника товариства з обмеженою відповідальністю $є$ необхідним і актуальним у контексті суттєвого оновлення законодавства в цій сфері.

Постановка завдання. Основними завданням статті $€$ визначення ролі статуту в механізмі правового регулювання корпоративних прав і обов'язків учасника товариства з обмеженою відповідальністю.

Результати дослідження. Відповідно до ч. 1 ст. 11 Закону України «Про товариства з обмеженою та додатковою відповідальністю», установчим документом товариства є статут [1]. Стату́т (лат. statutum, від лат. statuo - «встановлюю, вирішую») - встановлений засновни-

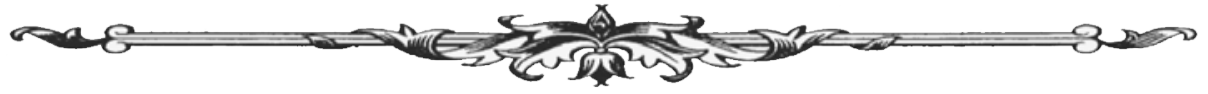


ком (власником майна) організації обсяг правил, що регулюють іії правовий стан, відносини, пов'язані із внутрішнім управлінням, стосунки з іншими організаціями чи громадянами [2].

Конституційний Суд України в абз. 3 свого рішення у справі № 1-3/2013 від 5 лютого 2013 р. закріплює, що статут є локальним правовим актом, обов'язковим для дотримання та виконання всіма учасниками [3]. Аналогічна позиція поширена і в сучасній юридичній літературі. Зокрема, науковці на підтвердження того, що статут $є$ локальним нормативним актом, слушно зазначають, що він затверджується засновниками під час створення товариства 3 метою визначення його правового статусу та містить загальнообов'язкові для всіх учасників корпоративних правовідносин правила поведінки (корпоративні норми) [4;5].

Загальні вимоги до змісту статуту містяться у ст. 88 Цивільного кодексу (далі - ЦК) України, ст. ст. 57, 82 Господарського кодексу (далі - ГК) України. У статуті товариства вказуються найменування юридичної особи, органи управління товариством, їхня компетенція, порядок ухвалення ними рішень, порядок вступу до товариства та виходу з нього, якщо додаткові вимоги щодо змісту статуту не встановлені цим Кодексом або іншим законом. Майже аналогічні вимоги містяться в ч. 5 ст. 11 Закону України «Про товариства з обмеженою та додатковою відповідальністю».

А. Яновицька вважає, що статут товариства з обмеженою відповідальністю повинен містити відомості про вид товариства, предмет і цілі його діяльності, склад засновників та учасників, найменування, розмір та порядок утворення статутного (складеного) капіталу, порядок розподілу прибутків і збитків, склад і компетенцію органів товариства та порядок ухвалення ними рішень, включаючи перелік питань, щодо яких необхідна кваліфікована більшість голосів, порядок внесення змін до установчих документів, порядок ліквідації та реорганізації товариства. Установчі документи товариства також повинні містити відомості про розмір часток кожного з учасників, розмір, склад і порядок внесення ними вкладів, розмір і порядок формування резервного фонду, порядок передання (переходу) часток у статутному капіталі [6, с. 118].

Загалом сучасні цивілісти зауважують, що у статуті врегульовані різнопорядкові відносини. Зокрема, статутом можуть регулюватися не конкретні відносини, а групи різноманітних відносин, як-от цивільно-правові, трудові, фінансово-правові тощо. Положення статуту є обов'язковими для ТзОВ, його учасників і трудового колективу, а також повинні враховуватися третіми особами в разі їх вступу у правовідносини з товариством [7].

Законодавство України надає можливість учасникам ТзОВ врегульовувати у статуті ті питання, які не врегульовані в законодавстві і можуть виникнути на практиці. Зокрема, учасникам чинне законодавство дозволяє закріпити у статуті широке коло відомостей, що стосуються різноманітних питань управління товариством, вступом до товариства і виходу 3 нього тощо. Варто звернути увагу на підхід законодавця до конструювання правових норм, які врегульовують суспільні відносини, пов'язані зі створенням і функціонуванням вищезазначених видів юридичних осіб. Д. Журавльов, О. Коротюк, К. Чижмарь щодо цього зазначають, що Закон України «Про товариства з обмеженою та додатковою відповідальністю» містить правові положення, які надають право особам, які створюють товариство, учасникам товариства, у разі досягнення згоди, в окремих випадках, відійти від запропонованої законом моделі поведінки і самостійно, за власним розсудом, створити ті чи інші норми установчого документа. Водночас окремі положення Закону відзначаються імперативністю і не підлягають зміні за домовленістю між суб'єктами правовідносин [8, с. 14].

Згідно $з$ нормами ст. 5 Закону України «Про товариства 3 обмеженою та додатковою відповідальністю», учасники товариства мають такі права: брати участь в управлінні товариством у порядку, передбаченому цим Законом та статутом товариства; отримувати інформацію про господарську діяльність товариства; брати участь у розподілі прибутку товариства; отримати в разі ліквідації товариства частину майна, що залишилася після розрахунків із кредиторами, або його вартість. Важливо усвідомлювати зайвість відтворення у статутах норм законів. У статутах варто передбачати лише те, що вимагається законом, а також ті положення, щодо яких закон припускає специфіку локального, автономного, своєрідного

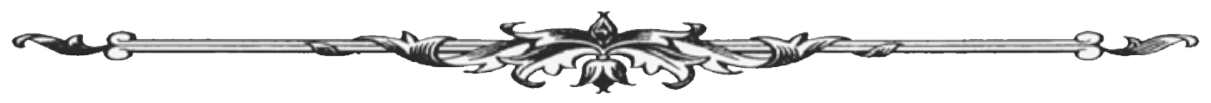


регулювання [9, с. 138]. Окрім прав, визначених у ст. 5 Закону України «Про товариства з обмеженою та додатковою відповідальністю», статутом можуть передбачатися інші права учасників (наприклад, може бути передбачено право учасника на переважну купівлі частки у статутному капіталі тощо). Крім того, інші права визначаються Законом і, зокрема, стосуються питань голосування на зборах, внесення частки у статутному капіталі, виходу з товариства, доступу до документів товариства й ін. Обмеження прав, визначених у цій нормі, не допускається [8, с. 14-15].

Відповідно до ст. 6 Закону України «Про товариства з обмеженою та додатковою відповідальністю», учасники товариства зобов’язані:

1) дотримуватися статуту;

2) виконувати рішення загальних зборів учасників товариства.

Учасники можуть мати обов'язки, встановлені законом і статутом товариства.

Крім обов'язків, вказаних у ст. 6 Закону, статутом може закріплюватися покладення на учасника інших обов'язків (наприклад, обов'язок сплатити частку у статутному капіталі протягом визначеного строку). Інші обов'язки також визначаються Законом і стосуються, наприклад, питань участі у зборах, виконання певних дій у разі виходу з товариства тощо. Зміна обов'язків, визначених у згаданій законодавчій нормі, не допускається.

Також варто звернути увагу на те, що за ст. 4 Закону України «Про товариства 3 обмеженою та додатковою відповідальністю» кількість учасників ТзОВ не є обмеженою. Ця норма має імперативний характер, ураховуючи це, можна припустити, що у статуті ТзОВ неприпустимо вказувати мінімальну або максимальну кількість учасників.

Статутом товариства можуть бути закріплені обмеження щодо зміни співвідношення часток учасників (ч. 3 ст. 12 Закону України «Про товариства з обмеженою та додатковою відповідальністю»). Відповідні положення можуть бути внесені до статуту, змінені або виключені з нього одностайним рішенням загальних зборів учасників, у яких взяли участь усі учасники товариства.

Це положення надає учасникам такі правомочності:

1) визначити у статуті розмір номінальної вартості часток у статутному капіталі кожного з учасників, а також, за бажанням, додатково зазначити розмір часток у відсотковому значенні;

2) встановити обмеження (наприклад, заборону) подальшої зміни співвідношення часток учасників (за умови одностайного голосування на загальних зборах усіх учасників товариства).

Отже, учасники не мають права:

1) визначити розмір частки у статутному капіталі в іншій валюті, ніж національна валюта України;

2) встановити співвідношення часток, що не відповідає співвідношенню значень номінальної вартості часток у статутному капіталі.

Ч. 3 ст. 12 Закону України «Про товариства з обмеженою та додатковою відповідальністю» дозволяє захистити інтереси учасників із невеликою часткою у статутному капіталі: зокрема, заблокувати можливість для учасника з більшістю голосів ухвалювати рішення про збільшення статутного капіталу за рахунок власного вкладу, що зменшить відсоток голосів інших учасників. Проте такі положення статуту повинні бути схвалені (а за потреби - змінені або виключені зі статуту) одностайним рішенням загальних зборів, у яких взяли участь всі учасники товариства [10].

Водночас мінімальний чи максимальний розмір статутного капіталу законом не визначається [8, с. 14-15].

Відповідно до ч. 2 ст. 21 Закону України «Про товариства 3 обмеженою та додатковою відповідальністю», статутом товариства може бути встановлено, що відчуження частки (частини частки) та надання іï в заставу допускається лише за згодою інших учасників. Відповідне положення може бути внесене до статуту або виключене 3 нього одностайним рішенням загальних зборів учасників, у яких взяли участь всі учасники товариства.

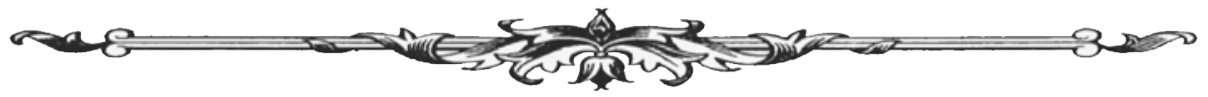


Згідно з положеннями ст. 45 Закону України «Про товариства з обмеженою та додатковою відповідальністю», статутом товариства може бути визначений порядок надання згоди на вчинення правочинів, щодо яких $€$ заінтересованість. Відповідні положення можуть бути внесені до статуту, змінені або виключені з нього одностайним рішенням загальних зборів учасників, у яких взяли участь усі учасники товариства.

За бажанням учасників ТзОВ може бути створене на підставі модельного статуту [11, с. 21]. Традиційно модельний статут уважають альтернативою звичайному статуту. Завданням модельного статуту є заміна індивідуального статуту. ТзОВ, не маючи власного статуту ТзОВ, буде діяти на підставі модельного (універсального статуту), затвердженого Кабінетом Міністрів України 27 березня 2019 р.[12], тобто безпосередньо на підставі нормативно-правового акта.

Модельний статут, на думку Т. Бровченко, $є$ нормативно-правовим актом, яким більш детально порівняно із законом урегульовуються корпоративні й інші відносини юридичної особи [9, с. 134].

В. Кочергіна дотримується думки, що модельний статут має ознаки дуалістичної правової природи нормативно-правового акта та ненормативного акта індивідуальної дії, що проявляється в його дії як затвердженого органом державної влади публічно-правового акта, обов'язкового для невизначеного кола осіб, і як внутрішнього (локального) правового акта, обов'язкового для визначеного кола осіб-учасників (засновників) і самої юридичної особи $[13$, c. 48]. Адже модельний статут не обов'язковий для всіх, поки засновники не вирішать діяти на його підставі. Тоді він одразу стає квазііндивідуальним, а насправді обов'язковим для цісї особи тому, що вона або іїі засновники погодилися діяти на підставі такого статуту.

У затвердженому Кабінетом Міністрів України модельному статуті 2019 р. містяться загальні положення про статус товариства з обмеженою відповідальністю, його учасників, статутний капітал, майно, прибутки і порядок їх використання. Окремо прописані функції органів товариства: загальних зборів, виконавчого органу, а також ревізійної комісії; порядок припинення товариства.

Щодо прав і обов'язків учасника ТзОВ варто зазначити, що модельний статут товариства 3 обмеженою відповідальністю містить альтернативні норми з урегулювання цих питань. Наприклад, відповідно до п. 15 цього модельного статуту, учасник ТзОВ має переважне право на придбання частки (частини частки) іншого учасника товариства, що продається третій особі, або, навпаки, не має переважного права на придбання частки (частини частки) іншого учасника товариства, що продається третій особі [12]. Це положення повною мірою відповідає п. 6 ст. 20 Закону України «Про товариства з обмеженою та додатковою відповідальністю», де зазначено, що статутом товариства може встановлюватися інший порядок реалізації переважного права учасників товариства, розподілу відчужуваної частки (частини частки) між іншими учасниками товариства, відмови від реалізації переважного права учасників товариства. Статутом може встановлюватися, що учасники товариства не мають переважного права.

Статутом також може бути передбачений обов'язок учасника товариства, який має намір продати частку (частину частки) третій особі, провести спершу переговори щодо іiі продажу з іншими учасниками товариства. Відповідні положення можуть бути внесені до статуту, змінені або виключені з нього одностайним рішенням загальних зборів учасників, у яких взяли участь усі учасники товариства.

Варто зауважити, що в чинному законодавстві міститься положення, що засновники юридичної особи, створеної на підставі модельного статуту, можуть затвердити статут і провадити діяльність на його підставі, і навпаки - юридична особа, засновниками якої затверджено статут, може ухвалити рішення продовжувати свою діяльність на підставі модельного статуту.

Висновки. Отже, статут ТзОВ відіграє надзвичайну велику роль у механізмі правового регулювання корпоративних прав і обов'язків учасника товариства 3 обмеженою відповідальністю. Він дозволяє не тільки деталізувати права й обов'язки учасників ТзОВ,

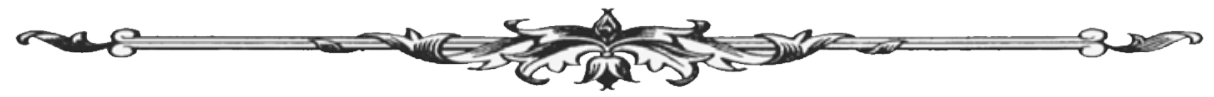


установлені в законодавстві, але і врегулювати відносини учасників. У новому Законі України «Про товариства з обмеженою та додатковою відповідальністю» наявні норми, які дають право особам, які створюють товариство, або учасникам товариства, в окремих випадках, відійти від запропонованої законом моделі поведінки і самостійно, за власним розсудом, створити ті чи інші норми установчого документа. Водночас інші норми цього законодавчого акта характеризуються імперативністю та не можуть бути змінені за домовленістю між суб'єктами правовідносин.

\section{Список використаних джерел:}

1. Про товариства з обмеженою та додатковою відповідальністю : Закон України від 6 лютого 2018 p. URL: https://zakon.rada.gov.ua/laws /show/2275-19.

2. Статут. Вікіпедія - вільна енциклопедія. URL: https://uk.wikipedia.org/wiki/Статут.

3. Рішення Конституційного Суду України у справі за конституційним зверненням Товариства $з$ обмеженою відповідальністю «Ліхтнер Бетон Львів» щодо офіційного тлумачення положень ч. 4 ст. 58, ч. 1 ст. 64 Закону України «Про господарські товариства», справа № 1-3/2013 від 5 лютого 2013 p. URL: http://zakon3.rada.gov.ua/laws/show/v001p710-13.

4. Бровченко Т. Зміст статуту товариств. Проблеми вдосконалення приватноправових механізмів набуття, передачі, здійснення та захисту суб'єктивних циивільних прав : матеріали Круглого столу, присвяченого пам'яті професора Чингізхана Нуфатовича Азімова, м. Харків, 18 грудня 2015 р. Харків, 2016. С. 188-191.

5. Тичкова О. Локальні корпоративні норми у цивільно-правовому регулюванні: автореф. дис. ... канд. юрид. наук: 12.00.03. Харків, 2009. 20 с.

6. Яновицька А. Статут і модельний статут як установчі документи суб'єктів господарювання - юридичних осіб. Науковий вісник Львівського державного університету внутрішніх справ. Серія «Юридична». 2016. Вип. 3. С. 116-123.

7. Цивільне право України. Загальна частина : підручник / за ред. О. Дзери, Н. Кузнєцової, Р. Майданика. 3-тє вид., перероб. і допов. Київ : Юрінком-Інтер, 2010. 976 с.

8. Журавльов Д., Коротюк О., Чижмарь К. Товариство з обмеженою відповідальністю за новим Законом: узагальнення законодавства, коментарі, зразки документів. Київ : ОВК, 2019. $64 \mathrm{c}$.

9. Бровченко Т. Установчі документи юридичних осіб за законодавством України : дис. ... канд. юрид. наук: 12.00.03. Харків, 2015. 230 с.

10. Токар М. Новий Закон про ТОВ: час оновити статут. Бухгалтерія UA. 2018. № 24. URL: https://buh-ua.com.ua/uk/doc/53330/novyj-zakon-ob-ooo-vremja-obnovit-ustav.

11. Смітюх А. Корпоративне право у схемах : навчальний посібник. Вид. 2, змін. і доп. Київ : Істина, 2012. 244 с.

12.Модельний статут товариства з обмеженою відповідальністю, затверджено постановою Кабінету Міністрів України від 27 березня 2019 р. № 367 «Деякі питання дерегуляції господарської діяльності». URL: https://zib.com.ua/ua/print/137480-modelniy_statut_ tov 2019 tekst.html.

13. Кочергіна В. Статут юридичної особи як правовий акт і підстава виникнення цивільних прав: актуальні питання теорії і практики. Юридична Україна. 2012. № 1. С. 47-50.

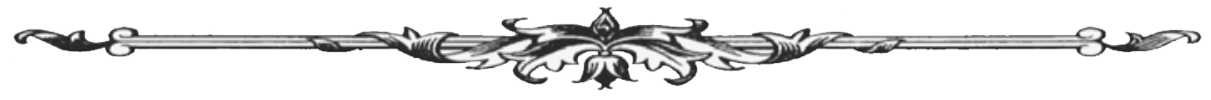

